\title{
ARTICLE
}

\section{Sensory Profiles of Koumiss with added Crude Ingredients extracted from Flaxseed (Linum usitatissimum L.)}

\author{
Dong-Hyeon $\mathrm{Kim}^{1 \dagger}$, Dana Jeong ${ }^{1 \dagger}$, Kwang-Young Song ${ }^{1^{*}}$, \\ Jung-Whan Chon ${ }^{1,2}$, Hyunsook $\mathrm{Kim}^{3}$, and Kun-Ho Seo ${ }^{1+}$ \\ ${ }^{1}$ Center for One Health, College of Veterinary Medicine, Konkuk University, Seoul, Korea \\ ${ }^{2}$ National Center for Toxicological Research, US Food and Drug Administration, Jefferson, USA \\ ${ }^{3}$ Dept. of Food \& Nutrition, College of Human Ecology, Hanyang University, Seoul, Korea
}

Received: August 29, 2017

Revised: September 24, 2017

Accepted: September 26, 2017

\author{
${ }^{\dagger}$ These authors contributed equally to \\ this study. \\ *Corresponding author : \\ Kwang-Young Song \\ Center for One Health, College of \\ Veterinary Medicine, Konkuk University, \\ Seoul 05029 South Korea. \\ Tel : +82-2-450-4121, \\ Fax : +82-2-3436-4128, \\ E-mail : drkysong@gmail.com
}

Copyright $\odot 2017$ Korean Society of Milk Science and Biotechnology.

This is an Open Access article distributed under the terms of the Creative Commons Attribution Non-Commercial License (http:// creativecommons.org/ licenses/by-nc/3.0) which permits unrestricted non-commercial use, distribution, and reproduction in any medium, provided the original work is properly cited.

\begin{abstract}
Recently, the health-promoting effects of functional foods have been shown to prevent nutrition-related diseases, improve physical and mental well-being, satisfy hunger, and provide necessary nutrients for the human body. Koumiss is a common type of fermented mare's milk that has been shown to have beneficial therapeutic effects on cardiovascular disease, tuberculosis, and diarrhea as it can nourish vessels, relieve ill mood, and improve digestion. Hence, in this study, we aimed to prepare health-promoting koumiss using different concentrations of flaxseed (Linum usitatissimmum L.), which has the potential to control heart disease, hypertension, inflammation, and lung function. The $\mathrm{pH}$ was decreased to around 4.42-4.43, whereas the total anthocyanin (TA) content was increased to around 0.78 0.82\% after fermentation of the koumiss premix. There were no significant differences in $\mathrm{pH}$ and TA among the three groups, including the control group. In sensory profile analysis, the taste, flavor, color, texture, and overall acceptability decreased in proportion to the added amount of flaxseed. These findings provided the first data describing the effects of flaxseed on koumiss fermentation, establishing a basis for commercial-scale production of koumiss containing fermented flax seed and for improving the health-promoting activity of koumiss.
\end{abstract}

\section{Keywords}

Linum usitatissimum L. (flaxseed), sensory profile, koumiss, Lactobacillus acidophilus ATCC43587, Lactobacillus kefiri DH5, Kluyveromyces marxianus DH6

\section{Introduction}

During the last 20 years, Linum usitatissimmum L. (flaxseed) had emerged as one of the important and attractive functional food ingredient among several food crops for developing functional foods. Since Linum usitatissimmum L. (flaxseed) had lots of desirable nutrient composition through various reported scientific literature. In fact, the trend of today foods would be intended to satisfy hunger with providing necessary nutrients for humans, and furthermore to control nutrition-related diseases with improving physical and mental well-being (Nothlings et al., 2007; Takachi et al., 2008). Namely, functional foods would be recognized quiet remedy. In general, Linum usitatissimmum L. (flaxseed) was a blue flowering rabi crop and a member of family Linaceae (Ganorkar and Jain, 2013). Proximate composition of flaxseed revealed that it was a rich source of alphalinolenic acid (ALA, omega-3, polyunsaturated fatty acid), protein, dietary fiber and lignan (Husain, 2008; Singh and Jood, 2009). Linum Usitatissimmum L. (flaxseed) oil or blends of flaxseed oil and sunflower oil promoted cholesterol reduction in hyper-cholesterolemic rats compared to diets formulated with hard fats (Ranhotra et al., 1993). Linum usitatissimmum L. (flaxseed) protein was effective in lowering plasma cholesterol 
and triglycerides (TAG) compared to soy protein and casein protein (Bhathena et al., 2002). Linum usitatissimmum L. (flaxseed) was a rich source of dietary fiber (accounting 28\%), both soluble as well as insoluble fibers (Morris, 2007). Soluble fiber and other components of Linum usitatissimmum L. (flaxseed) fraction could potentially affect insulin secretion and its mechanism of action in maintaining plasma glucose homeostasis. Lignans had antioxidant activity and thus could contribute to the anticancer activity of Linum usitatissimmum L. (flaxseed) (Kangas et al., 2002; Ganorkar and Jain, 2014).

Among various fermented milk products, Koumiss was a fermented mare milk beverage and also was popular in regions of Central Asia (Mongolia, Kazakhstan, Turkey, etc) and Eastern Europe (Danova et al. 2005). The production of the ancient beverage koumiss could be traced to the ancient Greeks and Romans in Europe (Wszolek et al., 2006). Also Koumiss had a long history as a popular drink among traditional nomadic people in China, and also had been considered as a complete food, rich in nutrients with medicinal properties. In general, Koumiss was a common fermented mare's milk with beneficial therapeutic effects on cardiovascular disease, tuberculosis, dyspepsia, abdominal tumors, and diarrhea as it could nourish vessels, relieve ill moods, and improve digestion (Thompson and Leamnington, 1879; Wu et al. 2009; Liu et al. 2011). Recently, Kazakhstan had introduced koumiss into military rations for preventing from tuberculosis (Ishii and Samejima, 2001). And Koumiss was rich in angiotensin I-converting enzyme inhibitory peptides, which had antihypertensive properties (Chen et al., 2010), and angiotensin I-converting enzyme inhibitory activity in yeast strains isolated from Colombian koumiss (Chaves-López et al., 2012). Yeasts were the main microorganisms in Koumiss which played an significant role in Koumiss fermentation and endowing them with its therapeutic effects (Khrisanfova 1969; Quan et al. 2006). Hence, the purpose of this study was to make the healthpromoting Koumiss added with Linum usitatissimmum L. (flaxseed) for improving sensory profiles as new concept taking several health benefits of Koumiss. Then, we analyzed sensory profiles including TA and $\mathrm{pH}$ of the health-promoting Koumiss added with Linum Usitatissimmum L. (flaxseed) produced in this experiment.

\section{Materials and Methods}

\section{Crude ingredients extracted from Linum usitatissim- mum L. (flaxseed)}

Linum Usitatissimmum L. (flaxseed) was provided from Center for One Health, College of Veterinary Medicine, Konkuk University in Seoul, Korea. The dried Linum Usitatissimmum L. (flaxseed) was macerated in 100\% sterilized distilled water for about 2 days with occasionally stirring at ambient temperature. Hence, the soluble ingredients were filtrated through $0.45 \mu \mathrm{m}$ Millipore and stored at $-20^{\circ} \mathrm{C}$ before use.

\section{Producing the health-prompting Koumiss added with} Linum usitatissimmum L. (flaxseed)

Crude ingredients extracted from Linum usitatissimmum L. (flaxseed) was added to premix of Koumiss at concentrations of $0 \%$ (control), 1, 2, 3\% and then homogenized. Lactobacillus acidophilus ATCC43587 and Lactobacillus kefiri DH5 as lactic acid bacteria and also Kluyveromyces marxianus DH6 as yeast were inoculated and fermented, and then the health-prompting Koumiss was stored at $4^{\circ} \mathrm{C}$ for $24 \mathrm{~h}$. The health-prompting Koumiss was made by modification of Lee et al. (2011) and Jeong et al. (2017) (Fig. 1)

\section{The $\mathrm{pH}$ and TA of the health-prompting Koumiss added with Linum usitatissimmum L. (flaxseed)}

The $\mathrm{pH}$ of the homogenized yoghurt was determined using a digital pH meter (Orion Star A211, USA), and the titratable acid (TA) was determined by titration with $0.1 \mathrm{~N} \mathrm{NaOH}$ and according to method of Jeong et al. (2017).

\section{Sensory profiles of the health-prompting Koumiss added with Linum usitatissimmum L. (flaxseed)}

The sensory profiles was carried out by 10 trained evaluators between 20 and 50 years of age. The samples were coded with three digit numbers and randomly served at about 7 to $10^{\circ} \mathrm{C}$ in plastic cups (approximately $10 \mathrm{~mL}$ ). All evaluators completed a test assessment form to compare the five sensory attributes (taste, flavor, color, and texture) by using a five-point hedonic scale (1, extremely poor; 2 , poor; 3, fair; 4, good; 5, excellent). More details please 


\begin{tabular}{|c|}
\hline $\begin{array}{c}\text { Koumiss premix } \\
(10 \% \text { reconstituted skim milk })\end{array}$ \\
\hline$\downarrow$ \\
\hline $\begin{array}{l}\text { Add crude extracts from Linum usitatissimmum L. (flaxseed) } \\
\qquad(0 \% \text { as control, } 1 \%, 2 \% \text {, and } 3 \%)\end{array}$ \\
\hline$\downarrow$ \\
\hline $\begin{array}{l}\text { Homogenization } \\
\left(25^{\circ} \mathrm{C} \text { for } 10 \mathrm{~min}\right)\end{array}$ \\
\hline$\downarrow$ \\
\hline $\begin{array}{l}\text { Pasteurization } \\
\text { (90 92 }{ }^{\circ} \mathrm{C} \text { for } 5 \text { min) }\end{array}$ \\
\hline$\downarrow$ \\
\hline $\begin{array}{l}\text { Cooling } \\
\left(30^{\circ} \mathrm{C}\right)\end{array}$ \\
\hline$\downarrow$ \\
\hline $\begin{array}{c}\text { Lactobacillus acidophilus ATCC43587 and } \\
\text { Lactobacillus kefiri DH5 } \\
\text { Lactic acid bacteria } \\
\left.\text { (30 }{ }^{\circ} \mathrm{C} \text { for } 24 \text { hours }\right)\end{array}$ \\
\hline$\downarrow$ \\
\hline $\begin{array}{l}\text { Cooling } \\
\left(15^{\circ} \mathrm{C}\right)\end{array}$ \\
\hline$\downarrow$ \\
\hline $\begin{array}{c}\text { Kluyveromyces marxianus DH6 } \\
\text { As Yeast } \\
\left(15{ }^{\circ} \mathrm{C} \text { for } 72 \text { hours }\right)\end{array}$ \\
\hline$\downarrow$ \\
\hline $\begin{array}{l}\text { Stirring and package } \\
\left(15^{\circ} \mathrm{C}\right)\end{array}$ \\
\hline$\downarrow$ \\
\hline $\begin{array}{l}\text { Cooling and storage } \\
\left(4{ }^{\circ} \mathrm{C} \text { for } 24 \text { hours) }\right.\end{array}$ \\
\hline
\end{tabular}

Fig. 1. Procedure for the manufacture of functional Koumiss added with Linum usitatissimmum L. (flaxseed).

refer to Table 2 .

Assays were performed in duplicate in at least three independent experiments and data are expressed as mean $( \pm \mathrm{SD})$.

\section{Statistical analysis}

Assays were performed in duplicate in at least three independent experiments and data are expressed as mean $( \pm S D)$. Statistical analysis was performed using one-way analysis of variance (ANOVA; SPSS 19.0, USA) followed by Duncan's post hoc test for mean comparison. Statistical significance was established as $p<0.05$.

\section{Results and Discussion}

\section{The $\mathrm{pH}$ and TA of the health-prompting Koumiss added with $0 \%$ to $3 \%$ Linum usitatissimmum L. (flaxseed)} Generally, the $\mathrm{pH}$ was high depending on the increase of the TA. And Koumiss could be divided by 3, (1) light type of Koumiss showed 4.5 to 5.0 of pH, 0.54 to 0.72 of titratable acidity, and 0.7 to 1.0 of alcohol contents, (2) moderate type of Koumiss showed 3.9 to 4.5 of $\mathrm{pH}, 0.73$ to 0.90 of titratable acidity, and 1.1 to 1.8 of alcohol contents, and (3) strong type of Koumiss showed 3.3 to 3.6 of pH, 0.91 to 1.08 of titratable acidity, and 1.8 to 2.5 of alcohol contents types (Robinsone et al., 2002; Danova et al., 2005). In this study, the $\mathrm{pH}$ was decreased to around 4.42 to 4.43 , but the TA was increased to around 0.78 to $0.82 \%$ after the fermentation of Koumiss premix (Data not shown). Hence, the $\mathrm{pH}$ and TA contents of the health-prompting Koumiss added with Linum usitatissimmum L. (flaxseed) (1\% to 3\%) showed the moderate type.

When compared to similar study, in the functional Koumiss added with Cichorium intybus L. (chicory), the $\mathrm{pH}$ was decreased to about 4.34 to 4.35 , the TA was increased to about 0.85 to $0.88 \%$, and and showed the moderate type in the functional Koumiss added with Cichorium intybus L. (chicory) (Jeong et al., 2017).

There was no significant difference among these 3 groups including control group in $\mathrm{pH}$ and TA in this study. Furthermore, the results of this study showed similar trend with the those of various previous studies (Robinson et al., 2002; Danova et al., 2005; Lee et al., 2011; Carrick, 2012; Zhang and Zhang, 2012; Jeong et al., 2017).

\section{Sensory profiles of the health-prompting Koumiss added with Linum usitatissimmum L. (flaxseed)}

The sensory profiles of the health-prompting Koumiss were evaluated by 10 trained evaluators of ages 20 to 50 years, and the results are summarized in Table 1.

The health-prompting Koumiss were prepared with Linum usitatissimmum L. (flaxseed) at concentrations of $0 \%, 1 \%$, $2 \%$, and $3 \%$, respectively. The taste scores for the healthprompting Koumiss with Linum usitatissimmum L. (flaxseed) 
(1\% to $3 \%)$ ranged from 2.9 point to 2.8 point, which were higher than those for conventional Koumiss without addition Linum usitatissimmum L. (flaxseed) ( $0 \%$ as control) (2.7 points). The flavor score of the health-prompting Koumiss with Linum usitatissimmum L. (flaxseed) (1\% to 3\%) ranged from 2.7 points to 2.5 point, whereas that of the conventional Koumiss without addition of Linum usitatissimmum L. (flaxseed) ( $0 \%$ as control) showed 2.7 points. The color value of the health-prompting Koumiss with Linum Usitatissimmum L. (flaxseed) (1\% to 3\%) ranged from 4.5 points to 4.3 point, which was comparable to that of conventional Koumiss without addition of Linum usitatissimmum L. (flaxseed) (0\% as control) showed 4.7 points. The texture of the health-prompting Koumiss with Linum usitatissimmum L. (flaxseed) (1\% to 3\%) and the conventional Koumiss without addition of Linum usitatissimmum L. (flaxseed) (0\% as control) showed about 4.3 points. And the overall acceptability of the health-prompting Koumiss with Linum Usitatissimmum L. (flaxseed) (1\% to 3\%) ranged from 3.6 points to 3.5 points, which was comparable to that of conventional Koumiss without addition of Linum usitatissimmum L. (flaxseed) (0\% as control) showed 3.6 points. Namely, the sensory profiles did not have sharply changed with increasing amounts of added Linum Usitatissimmum L. (flaxseed). Among the experimental group, high scores were received by Linum usitatissimmum L. (flaxseed)-containing Koumiss with $1 \%$ and $2 \%$ compared with the control group. Summarizing the results of this study, flavor, color, texture, and overall acceptability except the taste, decreased in proportion to the added amount of Linum usitatissimmum L. (flaxseed) (Table 1).

When compared to similar study, according to Jeong et al. (2017), the functional Koumiss was manufactured added with Cichorium intybus L. (chicory) at concentrations of $0 \%, 1 \%, 2 \%$, and $3 \%$, respectively. The sensory evaluation decreased with increasing amounts of added Cichorium intybus L. (chicory). The high scores were received by $\mathrm{Ci}^{-}$ chorium intybus L. (chicory)-containing Koumiss with 1\% compared with the control group. And the taste, flavor, color, texture, and overall acceptability generally decreased in proportion to the added amount of Cichorium intybus $\mathrm{L}$. (chicory). Also, according to Lee et al. (2011), Korean-type Koumiss was made using whey powder (0\% as control, 2\%, $4 \%, 6 \%$, and $8 \%$ ). When whey powder content increased in sensory evaluations, the scores increased. In the appearance, there were no great differences among the samples (Lee et al., 2011).

Recently, Interest in koumiss production has dramatically grown (IDF, 2009). Milk from eight species of domesticated mammals (cow, buffalo, sheep, goat, camel, horse, reindeer and yak) were used for making traditional fermented milk products, and there were three types of fermented milks(1) lactic fermentations, (2) yeast-lactic fermentations, and (3) mould (Geotrichum candidum)-lactic fermentations. Among them, koumiss and kefir belonged to the yeast-lactic fermentation group where alcoholic fermentation by yeasts was used in combination with a lactic acid fermentation (Tamine and Marshall, 1984). In general, koumiss contains about $90 \%$ moisture, $2 \sim 2.5 \%$ protein $(1.2 \%$ casein and $0.9 \%$ whey proteins), $4.5 \sim 5.5 \%$ lactose, $1 \sim 1.3 \%$ fat and $0.4 \sim 0.7 \%$ ash. The end-products of microbial fermentation in Koumiss were lactic acid (1.8\%), ethanol (0.6 3.0\%) and $\mathrm{CO}_{2}(0.5 \sim$ $0.9 \%$ ) and provided 37 to $40 \mathrm{kcal}$ per $100 \mathrm{~mL}$. Furthermore, Koumiss was thought to be more effective in disease treatment due to the additional peptides and bactericidal substances produced during microbial metabolism (Doreau and

Table 1. The sensory evaluation of the health-prompting Koumiss added with Linum usitatissimmum L. (flaxseed)

\begin{tabular}{ccccccc}
\hline \multirow{2}{*}{ Attributes } & \multicolumn{2}{c}{ Addition of Linum usitatissimmum L. (flaxseed) $(\%)$} & & A five-point hedonic scale \\
\cline { 2 - 3 } & 0 (Control) & 1 & 2 & 3 & & 1, extremely poor; 2, poor; 3, fair; 4, good; 5, excellent \\
\hline Taste & $2.7 \pm 0.4$ & $2.9 \pm 0.3$ & $2.9 \pm 0.5$ & $2.8 \pm 0.4$ & & The higher the intensity of the bitterness, the lower the score \\
Flavor & $2.7 \pm 0.4$ & $2.7 \pm 0.4$ & $2.7 \pm 0.4$ & $2.5 \pm 0.5$ & & The lower the intensity of Koumiss's aroma, the lower the score \\
Color & $4.7 \pm 0.4$ & $4.5 \pm 0.5$ & $4.4 \pm 0.6$ & $4.3 \pm 0.6$ & & The lower the intensity of the white color, the lower the score \\
Texture & $4.3 \pm 0.7$ & $4.3 \pm 0.6$ & $4.3 \pm 0.6$ & $4.3 \pm 0.6$ & & The lower the intensity of Koumiss's texture, the lower the score \\
Overall acceptability & $3.6 \pm 1.1$ & $3.6 \pm 0.9$ & $3.6 \pm 0.9$ & $3.5 \pm 1.0$ & & The higher the total score, the higher overall acceptability. \\
\hline
\end{tabular}

All points are expressed as mean $( \pm S D)$ of duplicate determinations.

Within a row, means with different superscripts are significantly different $(p<0.05)$. 


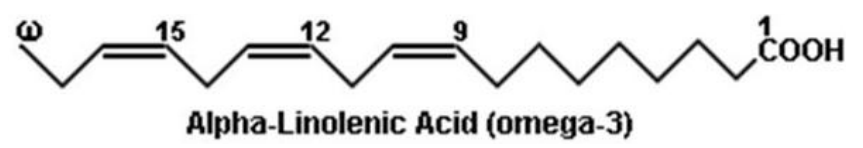

Fig. 2. Structure of alpha-linolenic acid (omega-3) Resource: XXX, year.

Marti-Rosset, 2002). According to the results of previous studies, Koumiss was found to have an beneficial effect on the chronic diseases such as tuberculosis, bronchitis, catarrh, anemia, and so on.

Alpha-linolenic acid (ALA) was a kind of omega-3 fatty acid found in plants, and seed oils were the richest sources of $\alpha$-linolenic acid, notably those of chia, perilla, flaxseed (linseed oil), rapeseed (canola), walnut oils, and soybeans (Fig. 2). In general, Alpha-linolenic acid was recognized as the omega-3 fatty acids called Eicosapentaenoic acid (EPA; 20:5, $n-3)$ and docosahexaenoic acid (DHA; 22:6, n-3) as fish oil. Human's body could change alpha-linolenic acid into EPA and DHA. Until now, Omega-3 fatty acids such as EPA and DHA had been shown to reduce inflammation and could help prevent chronic diseases as arthritis and heart disease. Furthermore, it could be very significant factors for brain's health and development. For preventing and treating heart disease, the best ways was to eat a diet with low level of saturated and trans fats but with rich level of monounsaturated and polyunsaturated fats, particularly omega-3 fatty acids. For example, the daily servings of Mediterranean Diet were contained fruit, fish and poultry, olive and canola oils, and alpha-linolenic acid (found in flaxseed oil). Also, when people follow a Mediterranean-style diet tend, they would have higher levels of High Density Lipoprotein (HDL, good cholesterol). Since a Mediterranean-style diet tend generally showed rich levels of alpha-linolenic acid. Especially, among various plants having alpha-linolenic acid, flaxseed oil contained the high in alpha-linolenic acid. Flaxseed oil effectively showed to help lower cholesterol owing to alpha-linolenic acid. The diets in rich level of omega-3 fatty acids could effectively reduce the blood pressure in people with hypertension. According to previous study, when people with hypertension ate the diet in rich contents of alpha-linolenic acid, it could lower the risk of high blood pressure by approximately 30\%. Until now, alpha-linolenic acid as omega-3 fatty acid could decrease inflammation and improve lung function in some people with asthma and improve dry eye that are comparable to those seen with corticosteroids. Especially the ALA was linked with improvements in dry eye and also linked with lower inflammatory markers among patients with chronic obstructive pulmonary disease (reference).

In summary, the $\mathrm{pH}$ was decreased and the TA was increased in the health-prompting Koumiss added with 0\%, $1 \%, 2 \%$, and $3 \%$ of Linum usitatissimmum L. (flaxseed), respectively, and in the sensory profiles, the health-prompting Koumiss containing $1 \%$ and $2 \%$ concentration of Linum usitatissimmum L. (flaxseed) received higher scores for taste, flavor, texture, and overall acceptability. Furthermore, it urgently needs further studies to make multi-purpose healthprompting Koumiss through upgraded availability of Linum usitatissimmum L. (flaxseed) for human.

\section{Disclaimer}

The views expressed herein do not necessarily reflect those of the US Food and Drug Administration or the US Department of Health and Human Services

\section{Acknowledgement}

This research was supported by Basic Science Research Program through the National Research Foundation of Korea (NRF) funded by the Ministry of Education (NRF2017R1D1A1B03035427).

\section{References}

Azay-Milhau, J., Ferrare, K., Leroy, J., Aubaterre, J., Tournier, M., Lajoix, A. 2013. Antihyperglycemic effect of a natural chicoric acid extract of chicory (Cichorium intybus L.): a comparative in vitro study with the effects of caffeic and ferulic acids. J. Ethnopharmacol. 150:755760.

Carazzone, C., Mascherpa, D., Gazzani, G., and Papetti, A. 2013. Identification of phenolic constituents in red chicory salads (Cichorium intybus) by high-performance liquid chromatography with diode array detection and electrospray ionisation tandem mass spectrometry. Food 
Chemistry. 138:1062-1071.

Carrick, G. L. 2012. Koumiss, or fermented mare's milk, and its uses in the treatment and cure of pulmonary consumption and other wasting. Ulan Press.

Danova, S., Petrov, K., Pavlov, P., and Petrova, P. 2005. Isolation and characterization of Lactobacillus strains involved in Koumiss fermentation. Society of Dairy Technology, 2:100-105.

Di Cagno, R., Tamborrino, A., Gallo, G., Leone, C., de Angelis, M., Faccia, M., Amirante, P., and Gobbetti, M. 2004. Uses of mares' milk in manufacture of fermented milks, International Dairy J. 14:767-775.

Dilanyan, S. H. 1959. Utilisation of mares', ewes', camels and yaks' milk in the USSR. Report, Int. Comm. Dairying in Warm Countries. Dairy Federation Brussels.

García-Peris, P., Velasco, C., Lozano, M. A., Moreno, Y., Paron, L., and de la Cuerda, C. 2012. Effect of a mixture of inulin and fructo-oligosaccharide on Lactobacillus and Bifidobacterium intestinal microbiota of patients receiving radiotherapy: a randomised, double-blind, placebocontrolled trial. Nutr. Hosp. 27:1908-1915.

Hao, Y., Zhao, L., Zhang, H., Zhai, Z., Huang, Y., Liu, X., and Zhang, L. 2010. Identification of the bacterial biodiversity in koumiss by denaturing gradient gel electrophoresis and species-specific polymerase chain reaction. J. Dairy Sci. 93:1926-1933.

Jeong, D., Kim, D. H., Chon, J. W., Kim, H., Kim, H. S., Song, K. Y., Kang, I. B., Kim, Y. J., Park, Y. H., Chang, H. S., and Seo, K. H. 2016. The antimicrobial activity of the crude extracts from Cichorim intybus L. (chicory) against Bacillus cereus in various dairy foods. J. Milk Sci. Biotechnol. 34:203-207.

Kamel, Z. H., Iman D., and Marzouk, M. 2011. Effect of Cichorium endivia leaves on some biochemical parameters in streptozotocin-induced diabetic rats. Australian Journal of Basic and Applied Sciences. 5:387-396.

Kang, S., Kim, S., Kim, D., Kim, H. S., Lee, S., Song, K., Yim, J., Kim, Y., Knag, I., Jeong, D., Park, J., Jang, H., Chon, J., Kim, H., and Seo, K. 2016. The manufacture on functional yogurt added with the crude materials extracted from Kaempferia parviflora. J. Milk Sci. Biotechnol. 34:181-186.

Kucukcetin, A., Yaygin, H., Hinrichs, H., and Kulozik, U.
2002. Adaptation of bovine milk towards mares' milk composition by means of membrane technology for Koumiss manufacture. International Dairy J. 13:945-951.

Lee, J. and Scagel, C. F. 2013. Chicoric acid: chemistry, distribution, and production. Front Chem. 1: 40. doi: 10. 3389/fchem.2013.00040.

Lee, J. K., Song, K. Y., Chon, J. W., Hyeon, J. Y, and Seo, K. H. 2011. Study on the manufacturing properties of Korean-type Koumiss. Korean J. Food \& Nutr. 24:367375.

Mu, Z., Yang, X., and Yuan, H. 2012. Detection and identification of wild yeast in Koumiss. Food Microbiol. 31:301-308.

Nishimura, M., Ohkawara, T., Kanayama, T., Kitagawa, K., Nishimura, H., and Nishihira, J. 2015. Effects of the extract from roasted chicory (Cichorium intybus L.) root containing inulin-type fructans on blood glucose, lipid metabolism, and fecal properties. Jouranl of Traditional and Complementary Medicine, 5:161-167.

Pourghassem, Gargari, B., Dehghan, P., Aliasgharzadeh, A., and Asghari, Jafar-Abadi, M. 2013. Effects of high performance inulin supplementation on glycemic control and antioxidant status in women with type 2 diabetes. Diabetes Metab J, 37:140-148.

Pushparaj, P. N., Low, H. K., Manikandan, J., Tan, B. K. H., and Tan, C. H.. 2007. Anti-diabetic effects of Cichorium intybus in streptozotocin-induced diabetic rats. Journal of Ethnopharmacology, 111:430-434.

Sabanci, S., Çokgezme, O. F., Tezcan, D., Çevik, M., and Içier, F. 2016. Effects of temperature on time dependent rheological characteristics of Koumiss. Turkish Journal of Agriculture-Food Science and Technology 4:262-266.

Sari, E. K., Bakir, B., Aydin, B. D., and Sozmen, M. 2014. The effects of kefir, koumiss, yogurt and commercial probiotic formulations on PPAR $\alpha$ and PPAR $-\beta / \delta$ expressions in mouse kidney. Biotechnic \& Histochemistry 89:287-295.

Scarpati, M. L. and Oriente, G. 1958. Chicoric acid (dicaffeyltartic acid): its isolation from chicory (Chicorium intybus) and synthesis. Tetrahedron 4:43-48.

Street, R. A., Sidana, J., and Prinsloo, G. 2013. Cichorium intybus: Traditional uses, phytochemistry, pharmacology, and toxicology. Evidence-Based Complementary and Al- 
ternative Medicine, Article ID 579319, 13 pages. http:// dx.doi.org/10.1155/2013/579319.

Wang, J., Chen, X., Liu, W., Yang, M., Airidengcaicike, and Hang, H. 2008. Identification of Lactobacillus from koumiss by conventional and molecular methods. Eur. Food Res. Technol. 227:1555-1561.

Zafar, R. and Mujahid Ali, S. 1998. Anti-hepatotoxic effects of root and root callus extracts of Cichorium intybus L.. Journal of Ethnopharmacology 63:227-231.

Zhang, W. and Zhang, H. 2012. Chapter 9. Fermentation and Koumiss. Handbook of animal-based fermented food and beverage technology ( $2^{\text {nd }}$ edition) writted by Hui YH, Özgül Evranuz E. CRC Press.

Zhao, W., Li, Y., Gao, P., Sun, Z., Sun, T., and Zhang, H. 2011. Validation of reference genes for real-time quantitative PCR studies in gene expression levels of Lactobacillus casei Zhang. J. Ind. Microbiol. Biotechnol. 38: 1279-86.

Zhao, Z. W., Pan, D. D., Wu, Z., Sun, Y. Y., Guo, Y. X., Zeng, X. Q. 2014. Antialcoholic liver activity of whey fermented by Lactobacillus casei isolated from koumiss. J. Dairy Sci. 97:4062-4071. 